\title{
Analisis Pengendalian Biaya Operasional Terhadap Profit Perusahaan CV. Bosch Cakrawala Sembada Musi Banyuasin
}

\author{
Oktariansyah \\ Akuntansi, FE Universitas PGRI Palembang \\ rianbro82@univpgri-palembang.ac.id
}

\begin{abstract}
ABSTRAK
Penelitian ini bertujuan untuk mengetahui pengendalian biaya operasional pada CV. Bosch Cakrawala Sembada Musi Banyuasin dengan cara menghitung selisih antara jumlah anggaran biaya operasional dikurangi dengan jumlah realisasi biaya operasional, kemudian menghitung kenaikan laba pertahunnya. Data yang diamati merupakan data laporan keuangan laba rugi CV. Bosch Cakrawala Sembada Musi Banyuasin pada tahun 2016 sampai dengan 2018. Analisa data dan pembahasan dengan menggunakan metode kualitatif. Metode penelitian ini diharapkan dapat ditarik sebagai metode penelitian yang bersifat interaktif dengan sumber data yang valid. Teknik analisa data yang dipakai ialah teknik analisa varians dan tingkat kenaikan laba. Dalam konsep biaya "Different cost different purpose" yang sangat berkaitan dengan perencanaan anggaran biaya dimana biaya yang dikeluarkan tidak melebihi dari pada biaya yang telah dianggarkan. Hasil pembahasan dapat diketahui bahwa pengendalian biaya pada CV. Bosch Cakrawala Sembada Musi Banyuasin masih belum maksimal dimana masih terdapat kelebihan realisasi biaya operasional.
\end{abstract}

Kata kunci: Biaya Operasional, konsep biaya

\section{A. PENDAHULUAN}

Dalam dunia perekonomian, teknologi sangat berperan penting yaitu sebagai alat bantu proses produksi barang atau jasa bagi perusahaan sekaligus merupakan ajang persaingan dimana perusahaan memproduksi barang dan jasa yang bervariasi untuk menarik konsumen. Teknologi telah mempengaruhi masyarakat dan sekelilingnya dalam banyak cara. Di banyak kelompok masyarakat, teknologi telah membantu memperbaiki ekonomi (termasuk ekonomi global masa kini) dan memungkinkan manusia untuk berinteraksi secara bebas dalam skala global.

Globalisasi

ekonomi mengakibatkan adanya pergeseran kekuasaan pasar. Pada era ini, konsumen yang menentukan produk dan jasa yang mereka butuhkan. Teknologi informasi dalam bentuk jaringan yang canggih, akan membantu produsen dalam mencari informasi mengenai kebutuhan tersebut. Globalisasi tidak hanya menambah jumlah pesaing di pasar melainkan menyebabkan semakin bervariasinya tingkat persaingan di pasar. Misalnya e-market atau jual beli online, dimana penjual memanjakan pembeli dalam memilih produk dengan harga bervariasi dari banyak clothing line (bisnis produksi/ desain pakaian) maupun toko yang lain.

Era pasar global yang di dalamnya customer memegang kendali, menuntut produsen untuk mengubah paradigma yang lebih kreatif dan kemapanan dalam pembuatan keputusan, sebab sekecil apapun keputusan yang dibuat akan berdampak bagi semua pihak. Oleh karena itu, Manajemen harus mampu mendapatkan informasi yang akurat untuk mengambil keputusan dalam produksi barang dan jasa namun harus memperhatikan biaya operasional yang telah direncanakan. 
Manajemen menetapkan tujuan yang dicapai dengan mengintegrasikan pengetahuan dan keahliannya dengan kemampuan karyawan. Dalam hal ini biaya sangat berperan penting bagi manajemen untuk melaksanakan fungsinya, terutama fungsi operasional yaitu sebagai alat untuk mengawasi pelaksanaan aktifitas perusahaan yang telah direncanakan, agar operasional perusahaan berjalan dengan tingkat efisien yang tinggi. Perencanaan dibuat dalam berbagai bidang, dan salah satunya bidang keuangan yaitu rencana yang dinilai dengan uang atau disebut anggaran yang mana terbagi dari perencanaan jangka pendek dan jangka panjang.

Menurut Kautsar (2016), anggaran adalah pernyataan tertulis mengenai rencana manajemen yang dapat dikuantifikasikan atau disajikan dalam bentuk kuantitatif. Dalam penyusunan anggaran, semua level manajemen harus terlibat sehingga memberikan motivasi para manajer dalam pencapaian tujuan yang telah ditetapkan. Anggaran yang realistis akan dapat meningkatkan koordinasi antar individu, tercapainya kebijakan manajemen, dan tercapainya tujuan yang telah ditetapkan. Biaya operasional (operating expenses) yaitu biaya berupa pengeluaran uang untuk melaksanakan kegiatan pokok, yang mana berupa biaya penjualan dan administrasi untuk memperoleh pendapatan.

CV. Bosch Cakrawala Sembada Musi Banyuasin merupakan suatu entitas yang bergerak dalam bidang penjualan dan penyewaan yang mana biaya operasionalnya sudah direncanakan, namun ada kalanya realisasi biaya opeasional melebihi biaya operasional yang sudah ditetapkan yang mana hal ini sangat berpengaruh pada pencapaian laba.
Pada tahun 2016 terjadi selisih biaya sebesar Rp. 15.899.312, pada tahun 2017 sebesar Rp. 3.710.208, dan pada tahun 2018 sebesar Rp. 3.220.344. dapat juga dilihat pengaruh pengendalian biaya operasional dari laporan laba/rugi dari tahun 2016-2018 meningkat. Hal ini dapat dilihat dari perhitungan rasio profitabilitas / tingkat kenaikan laba.

Pada tahun 2016 persentase laba usaha yang dilakukan oleh perusahaan sebesar 95,05 \%, pada tahun 2017 laba usaha mengalami naik menjadi $96,04 \%$, kemudian pada tahun 2018 laba usaha turun sebesar $79,99 \%$.

\section{B. KAJIAN TEORI \\ 1) Pengertian Biaya}

Menurut Wiwik dan Dhyka (2017), Biaya merupakan kas atau nilai ekuivalen kas yang dikorbankan untuk mendapatkan barang atau jasa yang diharapkan memberi manfaat saat ini atau di masa mendatang bagi organisasi.

Biaya (cost) juga didefinisikan sebagai "suatu nilai tukar, pengeluaran, pengorbanan yang dilakukan untuk menjamin perolehan manfaat" (Carter, 2009). Definisi tersebut merupakan definisi biaya secara konseptual.

Menurut Siregar, dkk (2016), Biaya yaitu kas barang atau jasa yang telah memberikan manfaat yang digunakan untuk memperoleh pendapatan. Biaya yang dikurangkan dari pendapatan untuk menentukan laba atau rugi pada suatu periode sehingga biaya akan dicantumkan dalam laporan laba rugi.

Sedangkan menurut Mulyadi (2010) biaya dalam artian luas adalah pengorbanan sumber ekonomi, yang diukur dalam satuan uang, yang telah terjadi atau yang kemungkinan akan terjadi untuk tujuan tertentu. Ada 4 
unsur pokok dalam definisi biaya tersebut di atas :

1. Biaya merupakan pengorbanan sumber ekonomi,

2. Diukur dalam satuan uang,

3. Yang telah terjadi atau yang secara potensial akan terjadi,

4. Pengorbanan tersebut untuk tujuan tertentu.

Jika pengorbanan sumber ekonomi tersebut tidak menghasilkan manfaat, maka pengorbanan tersebut merupakan rugi. Jika CV. Bosch Cakrawala Sembada Musi Banyuasin telah mengeluarkan biaya namun tidak mendatangkan

pendapatan (revenues), maka pengorbanan itu disebut rugi.

\section{2) Klasifikasi Biaya}

Biaya dikelompokkan sesuai dengan tujuan apa informasi biaya tersebut digunakan, sehingga dalam pengelompokkan biaya dapat digunakan suatu konsep "different cost different purpose" artinya berbeda biaya berbeda tujuan.

Klasifikasi biaya atau penggolongan biaya adalah suatu proses pengelompokkan biaya secara sistematis atas keseluruhan elemen biaya yang ada ke dalam golongangolongan tertentu yang lebih ringkas untuk dapat memberikan informasi yang lebih ringkas dan penting.

Klasifikasi biaya untuk digunakan adalah biaya dalam hubungan dengan:
a. Produk
b. Volume produksi
c. Departemen dan pusat biaya
d. Periode akuntasi
e. Pengambilan keputusan

\section{a) Biaya Produksi}

Biaya produksi adalah biaya yang digunakan dalam proses produksi yang terdiri dari bahan baku langsung, tenaga kerja langsung dan biaya overhead pabrik.
1. Biaya bahan baku langsung

Biaya bahan baku langsung adalah bahan baku yang merupakan bagian yang tidak dapat dipisahkan dari produk dan dapat ditelusuri langsung kepada produk selesai.

2. Tenaga kerja langsung

Tenaga kerja langsung adalah tenaga kerja yang digunakan dalam merubah atau mengkoversi bahan baku menjadi produk selesai dan dapat ditelusuri secara langsung kepada produk selesai.

3. Biaya overhead pabrik

Biaya overhead pabrik adalah biaya selain bahan baku langsung dan tenaga kerja langsung tetapi membantu masalah dalam merubah bahan menjadi produk selesai.

Biaya overhead pabrik dapat dikelompokkan menjadi elemen:

a. Bahan tidak langsung (pembantu atau penolong), bahan ini adalah bahan yang digunakan dalam penyelesaian produk tetapi pemakaiannya relatif lebih kecil dan biaya ini tidak dapat ditelusuri secara langsung kepada produk selesai.

b. Tenaga kerja tidak langsung, tenaga kerja ini adalah tenaga kerja yang membantu dalam pengolohan produk selesai, tetapi tidak dapat ditelusuri kepada produk selesai.

c. Biaya tidak langsung lainnya, biaya tidak langsung lain adalah biaya selain bahan tidak langsung dan tenaga kerja tidak langsung yang membantu dalam pengolohan produk selesai, tetapi tidak dapat ditelusuri kepada produk selesai.

Unsur utama biaya produksi dapat digolongkan secara terminologi biaya sebagai berikut: 
1. Biaya utama, yaitu gabungan antara biaya bahan baku langsung dan biaya tenaga kerja langsung.

2. Biaya konversi, yaitu biaya yang digunakan untuk merubah bahan baku langsung menjadi produk selesai. Biaya ini merupakan gabungan dari biaya tenaga kerja langsung dan biaya overhead pabrik.

\section{b) Biaya Non Produksi}

Biaya non produksi adalah biaya yang tidak terhubung dengan proses produksi. Biaya ini juga disebut biaya komersial atau biaya operasi. Biaya ini dikelompokkan menjadi biaya:

1. Beban pemasaran atau biaya penjualan, adalah biaya yang dikeluarkan apabila produk selesai dan siap dipasarkan ketangan konsumen.

2. Beban administrasi, adalah biaya yang dikeluarkan dalam hubungan dengan kegiatan penentu kebijakkan, pengarahan, pengawasan kegiatan perusahaan secara keseluruhan agar dapat berjalan dengan efektif dan effisien.

3. Beban keuangan, adalah biaya yang muncul dalam melaksanakan fungsi-fungsi keuangan. Misalnya: beban bunga.

\section{3) Biaya Operasional}

\section{a) Pengertian Biaya Operasional}

Secara umum biaya operasional diartikan sebagai biaya yang terjadi dalam kaitannya dengan operasi yang dilakukan perusahaan dan diukur dalam satuan uang. Dimana biaya operasi sering disebut juga sebagai operational cost atau biaya usaha.

Menurut kamus akuntansi yang dibuat oleh Syahrul dan Nizar (2000) pengertian biaya operasional adalah biaya-biaya yang berkaitan dengan kegiatan-kegiatan administratif dan penjualan dari suatu perusahaan. Disebut juga non manufacturing expense. Merupakan biaya periode yang berkaitan dengan waktu, bukan dengan produk. Biaya ini dibagi atas biaya penjualan dan biaya administrasi umum.

Menurut Rudianto (2013), merupakan biaya untuk memasarkan produk perusahaan sehingga sampai ke tangan konsumen beserta keseluruhan biaya yang berkaitan dengan proses administratif yang dilakukan perusahaan. Biaya tersebut ialah biaya pemasaran dan biaya administrasi dan umum.

Mulyadi (2007), mengemukakan pengertian biaya operasional sebagai biaya-biaya yang terjadi untuk mengolah bahan baku menjadi produk jadi yang siap untuk dijual. Contohnya adalah biaya depresiasi mesin, equipment, biaya bahan baku, biaya penolong, biaya gaji karyawan yang bekerja dalam bagian-bagian baik yang langsung maupun tidak langsung berhubungan dengan proses produksi.

Selain pengertian diatas, biaya operasional dapat juga diartikan sebagai pengeluaran yang masa manfaatnya tidak lebih dari satu tahun atau pengeluaran yang dikaitkan secara langsung dengan pendapatan dalam suatu periode tertentu atau dengan kata lain merupakan biaya yang dikeluarkan yang ada pada hakikatnya dianggap terpakai dalam masa satu tahun.

Dalam biaya operasional tersebut sudah termasuk segala pemeliharaan suatu aktivitas dan peralatan milik perusahaan serta biaya penggantian bagian-bagian peralatan untuk mempertahankan norma-norma teknis yang ada. Begitu pula biaya perolehan aktiva yang nilainya dianggap kurang berarti atau dianggap mempunyai masa manfaat kurang dari satu tahun.

Dari pengertian biaya operasional diatas bahwa biaya operasional 
merupakan biaya-biaya yang digunakan untuk memperoleh barang, menghasilkan barang, melakukan pemasaran dan melakukan penjualan serta biaya-biaya untuk operasional lain jika perusahaan tersebut adalah manufaktur. Jika perusahaannya adalah perusahaan dagang maka biaya operasionalnya adalah biaya untuk memperoleh barang dagangan, pemasaran dan kegiatan penjualan serta biaya-biaya operasional perusahaan lain.

\section{b) Jenis-jenis Biaya Operasional}

Biaya operasi atau biaya usaha merupakan biaya yang secara langsung berhubungan dengan operasi pokok perusahaan. "Biaya operasional terbagi menjadi tiga kelompok, antara lain: biaya pabrik, biaya administrasi, dan biaya penjualan".

Adapun uraian dari klasifikasi diatas tersebut adalah sebagai berikut: 1. Biaya pabrik (factory cost) yaitu semua biaya yang terjadi serta terdapat di dalam lingkungan tempat dimana tempat proses produksi berlangsung, terdiri dari biaya bahan mentah (direct material), upah tenaga kerja langsung (direct labour), biaya pabrik tidak langsung (factory overhead).

2. Biaya administrasi (administration expense) yaitu semua biaya yang terjadi di dalam lingkungan kantor administrasi perusahaan, serta biayabiaya lain yang sifatnya untuk keperluan administrasi perusahaan secara keseluruhan, terdiri dari:

a. Gaji karyawan kantor (office salaries), adalah gaji yang dibayarkan kepada karyawan di kantor administrasi.

b. Gaji pemeliharaan kantor (office maintenance), adalah biaya untuk pemeliharaan ruang dan peralatan kantor administrasi. c. Biaya perbaikan kantor (office repair), adalah biaya perbaikan ruang dan peralatan administrasi.

d. Depresiasi peralatan kantor (depreciation of office funiture), adalah biaya depresiasi terhadap peralatan kantor administrasi.

e. Depresiasi gedung bagian administrasi (depreciation of state building), adalah depresiasi terhadap bangunan (gedung) kantor administrasi.

f. Biaya listrik kantor, adalah biaya listik untuk keperluan kantor administrasi.

g. Biaya asuransi kantor (office insurance), adalah biaya asuransi terhadap bangunan serta peralatan kantor administrasi.

h. Biaya supplies kantor (office supplies), adalah biaya-biaya ubtuk keperluan menulis serta keperluan kecil lainnya di kantor administrasi.

3. Biaya Penjualan (selling expense), yaitu semua biaya yang terjadi serta terdapat di dalam lingkungan di bagian penjualan, serta biaya-biaya lain yang berhubungan dengan kegiatan-kegiatan yang dilakukan oleh bagian penjualan. Biaya penjualan terdiri dari:

a. Gaji karyawan penjualan (store salaries), adalah gaji yang dibayarkan kepada karyawan di bagian penjualan.

b. Biaya pemeliharaan ruang dan peralatan (store maintanance), adalah biaya untuk pemeliharaan ruang dan peralatan bagian penjualan.

c. Biaya perbaikan bagian penjualan (store repair), adalah biaya untuk perbaikan ruang dan peralatan bagian penjualan.

d. Depresiasi peralatan bagian penjualan (depreciation of store building), adalah beban 
depresiasi terhadap beban bangunan bagian penjualan.

e. Biaya listrik bagian penjualan (store heat and light), adalah biaya listrik untuk keperluan bagian penjualan.

f. Biaya telepon bagian penjualan (store telephone), adalah biaya telepon untuk keperluan bagian penjualan.

g. Biaya supplies bagian penjualan (store supplies), adalah biaya untuk keperluan menulis serta keperluan kecil lainnya di bagian penjualan.

h. Biaya advertensi (advertising expense), adalah biaya pemasangan iklan di berbagai media masa untuk keperluan meningkatkan penjulan produk yang dihasilkan.

c) Pengendalian Biaya Operasional Menurut Kautsar (2016), Pengendalian merupakan usaha sistematis untuk mencapai tujuan secara efektif dan efisien dengan cara membandingkan prestasi kerja dengan rencana dan membuat tindakan yang tepat untuk mengoreksi perbedaan yang ada. Berbagai tindakan harus selalu dikontrol dengan harapan untuk diketahui apakah sesuai dengan rencana yang telah ditetapkan.

Menurut Siregar, dkk (2016), Pengendalian merupakan usaha sistematis yang dilakukan manajemen untuk mencapai tujuan secara efisien dan efektif. Pengendalian dilaksanakan dengan membandingkan kinerja dengan rencana dan mengambil tindakan yang perlu untuk menghilangkan berbagai penyimpangan.

Pengendalian biaya harus didahului dengan penentuan biaya yang seharusnya dikeluarkan untuk memproduksi satu satuan produk. Jika biaya seharusnya ini ditetapkan, akuntansi biaya bertugas untuk memantau apakah pengeluaran biaya yang sesungguhnya sesuai biaya yang seharusnya tersebut. Aspek perilaku manusia dalam akuntansi biaya untuk tujuan biaya adalah besar. Oleh karena itu, informasi yang didapatkan haruslah benar sehingga tidak adanya penyimpangan biaya yang terjadi.

Manajemen harus teliti dan tegas dalam urusan biaya, karena dalam konsepnya "different cost, different purpose" yang artinya berbeda biaya, berbeda tujuan, dimana biaya yang anggaran yang direncanakan harus sesuai dengan rencana yang telah dibuat. Melalui proses membandingkan hasil yang sesungguhnya dengan anggaran yang disusun, maka manajemen dapat melakukan penilaian atas efisiensi usaha dan kemampuan memperoleh laba usaha dari berbagai produk.

Dari pengertian diatas bahwa pengendalian biaya operasional adalah suatu aktivitias organisasi dalam mengendalian biaya untuk mendapatkan tujuan yang diharapkan dengan pengambilan keputusan khusus manajemen menyangkut masa yang akan datang. Oleh karena itu, informasi yang relevan dengan pengambilan keputusan khusus selalu berhubungan dengan informasi masa yang akan datang.

\section{4) Anggaran (Budget)}

a) Pengertian Anggaran

Menurut Wiwik dan Dhyka (2017), Anggaran adalah pernyataan kuantitatif dari rencana tindakan yang dibuat oleh manajemen untuk periode tertentu dan suatu alat bantu untuk mengoordinasinakan hal-hal yang mendukung penerapan rencana tersebut. Anggaran induk memiliki dua bagian utama termasuk anggaran operasional dan anggaran keuangan. Anggaran operasional dimulai dengan anggaran penjualan dan berakhir 
dengan laporan laba rugi. Berdasarkan rentang waktu anggaran meliputi jangka panjang dan jangka pendek.

Anggaran merupakan salah satu alat usaha perusahaan dalam mencapai tujuannya, setiap perusahaan harus membuat anggaran baik perusahaan kecil maupun perusahaan yang besar. Anggaran merupakan sarana utama dalam perencanaan, pengendalian, penetapan harga serta dalam pengambilan keputusan. Anggaran dinyatakan dalam satuan uang dan satuan moneter yang mana diharapkan mampu mencapai sasaran perusahaan dalam waktu tertentu.

\section{b) Fungsi Anggaran}

Manfaat anggaran dapat berupa:

1. Menerjemahkan dan mengoperasionlakan perencanaan strategis

2. Menyediakan referen untuk perencanaan

3. Memotivasi pimpinan dan karyawan

4. Meningkatkan koordinasi

Menurut Wiwik dan Dhyka (2017), adapun manfaat lainnya, yaitu:

1. Perencanaan

Pertama dengan penentuan tujuan, kemudian strategi pokok yang akan digunakan untuk mencapai tujuan tersebut, tahap selanjutnya penyusunan strategi untuk setiap pusat pertanggung jawaban.

\section{Koordinasi}

Anggaran berfungsi sebagai alat untuk mengkoordinasi rencana dan tindakan berbagai unit yang ada di dalam organisasi agar dapat berkerja secara selaras ke arah pencapaian tujuan.

\section{Komunikasi}

Organisasi yang berfungsi secara efisisen merupakan hal yang paling diharapkan dalam dunia manajemen, maka organisasi tersebut harus menentukan saluran komunikasi melalui berbagai unit dalam organisasi tersebut.

4. Motivasi

Anggaran dapat berfungsi sebagai alat untuk memotivasi para pelaksana di dalam melaksanakan tugas-tugasnya untuk mencapai tujuan yang telah ditetapkan.

5. Pengendalian dan evaluasi

Anggaran berfungsi sebagai alat pengendalian kegiatan karena anggaran yang sudah disetujui merupakan komitmen dari para pelaksana yang ikut berperan di dalam penyusunan anggaran tersebut. Pengendalian pada dasarnya adalah membandingkan antara rencana dengan pelaksanaan sehingga dapat ditentukan penyimpangan yang timbul apakah sudah menjadi "emergency sign" bagi organisasi tersebut.

\section{5) Laba}

Dilansir dari Wikipedia (2017), laba (profit) didefinisikan dengan dua cara yang pertama Laba dalam ilmu ekonomi murni didefinisikan sebagai peningkatan kekayaan seorang investor sebagai hasil penanam modalnya, setelah dikurangi biayabiaya yang berhubungan dengan penanaman modal. Sementara itu, laba dalam akuntansi didefinisikan sebagai selisih antara harga penjualan dengan biaya produksi.

$$
\text { Laba (profit) merupakan }
$$

ringkasan hasil bersih aktivitas operasi laba tertentu yang dinyatakan dalam istilah keuangan. Laba (earning) atau laba bersih (net income mengidikasikan profitabilitas perusahaan. Laba mencerminkan pengembalian kepada pemegang ekuitas untuk suatu periode. Laba merupakan perkiraan atas kenaikan (atau penurunan) atas laporan keungan yang juga termasuk dalam 
laba operasi. Laba operasi ialah selisih antara penjualan dengan seluruh biaya dan beban operasi.

Berdasarkan definisi diatas, laba merupakan keuntungan yang diperoleh perusahaan dari kegiatan penjualan sebagi selisih dari biaya usaha yang dikeluarkan.

\section{METODE PENELITIAN}

Menurut Sugiyono (2017), Metode penelitian merupakan cara ilmiah untuk mendapatkan data dengan tujuan dan kegunaan tertentu. Terdapat dua jenis metode penelitian yang digunakan yaitu:

1. Metode penelitian kualitatif

Metode penelitian kualitatif yaitu metode-metode penelitian yang berdasarkan pada filsafat ketidakpastian digunakan untuk meneliti pada kondisi objek yang alamiah (sebagai lawannya adalah experimen).

2. Metode penelitian kuantitatif

Metode penelitian kuantitatif dapat diartikan sebagai metode penelitian yang berlandaskan pada kepastian (data) yang berupa angkaangka, digunakan untuk meneliti pada populasi atau sampel tertentu.

Dalam penelitian ini metode yang digunakan adalah metode kualitatif. Metode penelitian ini diharapkan dapat ditarik sebagai metode penelitian yang bersifat interaktif dengan sumber data yang valid.

\section{POPULASI DAN SAMPEL}

\section{1) Populasi}

Menurut Sugiyono (2017),

Populasi adalah wilayah generalisasi yang terdiri atas: obyek/subyek yang mempunyai kualitas dan karakteristik tertentu yang ditetapkan oleh peneliti untuk dipelajari dan kemudian ditarik kesimpulan.

Populasi dalam penelitian ini adalah laporan keuangan perusahan
CV. Bosch Cakrawala Sembada Musi Banyuasin yang bergerak di bidang penjualan. Penentuan populasi dilakukan untuk mendapatkan data dan kesimpulan terkini dari objek yang akan diteliti.

2) Sampel

Menurut Sugiyono (2017), Sampel adalah bagian jumlah karakteristik dari populasi yang diteliti. Oleh karena itu sampel yang diambil harus benar-benar mewakili.

Dalam penelitian ini sampel yang digunakan adalah laporan laba / rugi pada CV. Bosch Cakrawala Sembada Musi Banyuasin pada tahun 2016 sampai dengan 2018.

\section{TEKNIK PENGUMPULAN DATA}

Menurut Sugiyono (2017), merupakan langkah yang paling strategis dalam penelitian, karena tujuan utama dari penelitian adalah untuk mendapatkan data. Adapun teknik data yang dilakukan adalah dengan cara dokumentasi yaitu :

1. Dokumentasi

Dokumentasi merupakan teknik yang digunakan untuk mencari hal-hal atau variabel yang berupa catatan, transkrip, buku, agenda, dan lain sebagainya untuk mendapatkan data yang diperlukan seperti anggaran, realisasi anggaran pendapatan dan biaya operasional, dan laporan keuangan bagi peneliti menggunakan arsip-arsip yang ada diperusahaan untuk dipergunakan dalam penelitian.

\section{Studi Pustaka}

Studi pustaka merupakan teknik pengumpulan data yang dilakukan dengan cara membaca literatur yang berhubungan dengan pembahasan skripsi.

\section{E. TEKNIK ANALISIS DATA}

Menurut Sugiyono (2017), Teknik analisa data adalah proses mencari 
dan menyusun secara sistematis data yang diperoleh dari hasil wawancara, catatan lapangan, dan dokumentasi, dengan cara mengorganisasikan data kedalam kategori, menjabarkan ke unit-unit, melakukan sintesa, menyusun kedalam pola, memilih mana yang penting dan yang akan dipelajari, dan membuat kesimpulan sehingga mudah dipahami oleh diri sendiri maupun orang lain.

Berdasarkan teori diatas dalam suatu penelitian terdapat dua metode, yaitu : metode analisis deksriptif kuantitatif dan kualitatif. Teknik analisa data yang digunakan metode analisis deskriptif kuantitatif yaitu salah satu pendekatan yang digunakan untuk menganalisa data-data yang diperoleh untuk dihitung oleh peneliti melalui teknik analisa yang telah ditentukan. Hal ini dilakukan agar terciptanya efisiensi biaya operasional yang dikeluarkan perusahaan.

Teknik analisa data yang akan digunakan peneliti dalam menganalisa pengendalian biaya operasional terhadap profit yang dilakukan CV. Bosch Cakrawala Sembada Musi Banyuasin adalah sebagai berikut :

1. Analisa Varians

Varians adalah perbedaan antara jumlah yang didasarkan pada hasil aktual dan jumlah yang dianggarkan, jumlah yang dianggarkan merupakan acuan untuk melakukan perbandingan.

Setiap varians merupakan suatu sinyal yang sebaiknya diidentifiaksi dan analisa. Suatu varians dapat disebabkan oleh kejadian acak yang tidak diharapakan terulang kembali, masalah sistematis yang dapat diperbaiki, atau standar yang tidak tepat. Misalnya, jika proses manufaktur berubah, maka standar fisik juga mungkin berubah.

Ada dua jenis varians, yaitu :

a. Varians yang digunakan favorable, adalah varians yang memiliki pengaruh meningkatkan laba operasi relatif terhadap jumlah yang dianggarkan.

b. Varians yang tidak menguntungkan unfavorable adalah varians yang memiliki pengaruh menurunkan laba operasi relatif terhadap jumlah yang dianggarkan.

\section{BOPO (Biaya Operasional} Pendapatan Operasional)

Teknik ini dipakai untuk membandingkan biaya operasional dibagi dengan pendapatan lalu dikali dengan $100 \%$ sehingga menghasilkan persentase laba yang diperoleh perusahaan dalam suatu periode. Rumus yang digunakan :

BOPO $=\frac{\text { Biaya Operasional }}{\text { Pendapatan }} \times 100 \%$

\section{F. HASIL PENELITIAN}

Berdasarkan hasil analisis pengendalian biaya operasional terhadap laporan laba rugi pada CV. Bosch Cakrawala Sembada Musi Banyuasin dari tahun 2016 dan 2018 bahwa jumlah realisasi anggaran lebih besar dari jumlah anggaran dimana pada tahun 2016 jumlah realisasi anggaran sebesar Rp.168.699.312 dan jumlah anggarannya sebesar Rp.152.800.000. Sedangkan pada tahun 2017 jumlah realisasinya sebesar Rp.136.460.208 daan jumlah anggaran sebesar Rp.132.750.000.

Pada tahun 2018 pengendalian biaya operasional sudah mulai terkendali dimana jumlah realisasi anggaran lebih kecil dari jumlah anggaran. Dimana jumlah realisasi sebesar Rp.184.210.156 sedangkan jumlah anggarannya sebesar Rp.187.430.500.

Dalam hal ini peneliti mendapatkan data keuangan dari CV. 
Bosch Cakrawala Sembada Musi Banyuasin berupa laporan laba rugi selama 3 periode akuntansi yaitu tahun 2016 sampai dengan 2018.
Berikut ini akan disajikan laporan keuangan CV. Bosch Cakrawala Sembada Musi Banyuasin selama 3 tahun:

Tabel 1

Laporan L/R CV. Bosch Cakrawala Sembada Musi Banyuasin Periode 31 Desember 2016

\begin{tabular}{|c|c|}
\hline Keterangan & Dalam Rupiah \\
\hline $\begin{array}{l}\text { Pendapatan Usaha: } \\
\text { - Pendapatan Jual-Beli \& Sewa Mesin } \\
\text { Fotocopy } \\
\text { - Pendapatan Fotocopy } \\
\text { - Harga Pokok Usaha } \\
\text { Laba Bruto }\end{array}$ & $\begin{array}{l}175.486 .640 \\
\underline{2.000 .000}+ \\
\underline{141.989 .312}-\end{array}$ \\
\hline $\begin{array}{l}\text { Biaya Operasional : } \\
\text { Administrasi dan Umum : } \\
\text { - Biaya Listrik + Telp + Air PAM } \\
\text { - Biaya Kebutuhan Kantor } \\
\text { Total Biaya Umum dan Administrasi }\end{array}$ & $\begin{array}{c}8.755 .000 \\
17.955 .000\end{array}$ \\
\hline Laba Bersih Sebelum Pajak & 8.787 .328 \\
\hline
\end{tabular}

Sumber : CV. Bosch Cakrawala Sembada Musi Banyuasin

Tabel 2

Laporan L/R CV. Bosch Cakrawala Sembada Musi Banyuasin Periode 31 Desember 2017

\begin{tabular}{|c|c|}
\hline Keterangan & Dalam Rupiah \\
\hline $\begin{array}{l}\text { Pendapatan Usaha: } \\
\text { - Pendapatan Jual-Beli \& Sewa Mesin } \\
\text { Fotocopy } \\
\text { - Harga Pokok Usaha } \\
\text { Laba Bruto }\end{array}$ & $\begin{array}{l}142.081 .510 \\
\underline{113.665 .208}+\end{array}$ \\
\hline $\begin{array}{l}\text { Biaya Operasional : } \\
\text { Biaya Administrasi dan Umum : } \\
\begin{array}{ll}\text { - } & \text { Biaya Listrik + Telp + Air PAM } \\
\text { Total Biaya Umum dan Administrasi }\end{array}\end{array}$ & $\begin{array}{c}7.545 .000 \\
15.250 .000+ \\
\end{array}$ \\
\hline Laba Bersih Sebelum Pajak & $\underline{5.621 .302}$ \\
\hline
\end{tabular}

Sumber : CV. Bosch Cakrawala Sembada Musi Banyuasin 
Tabel 3

Laporan L/R CV. Bosch Cakrawala Sembada Musi Banyuasin Periode 31 Desember 2018

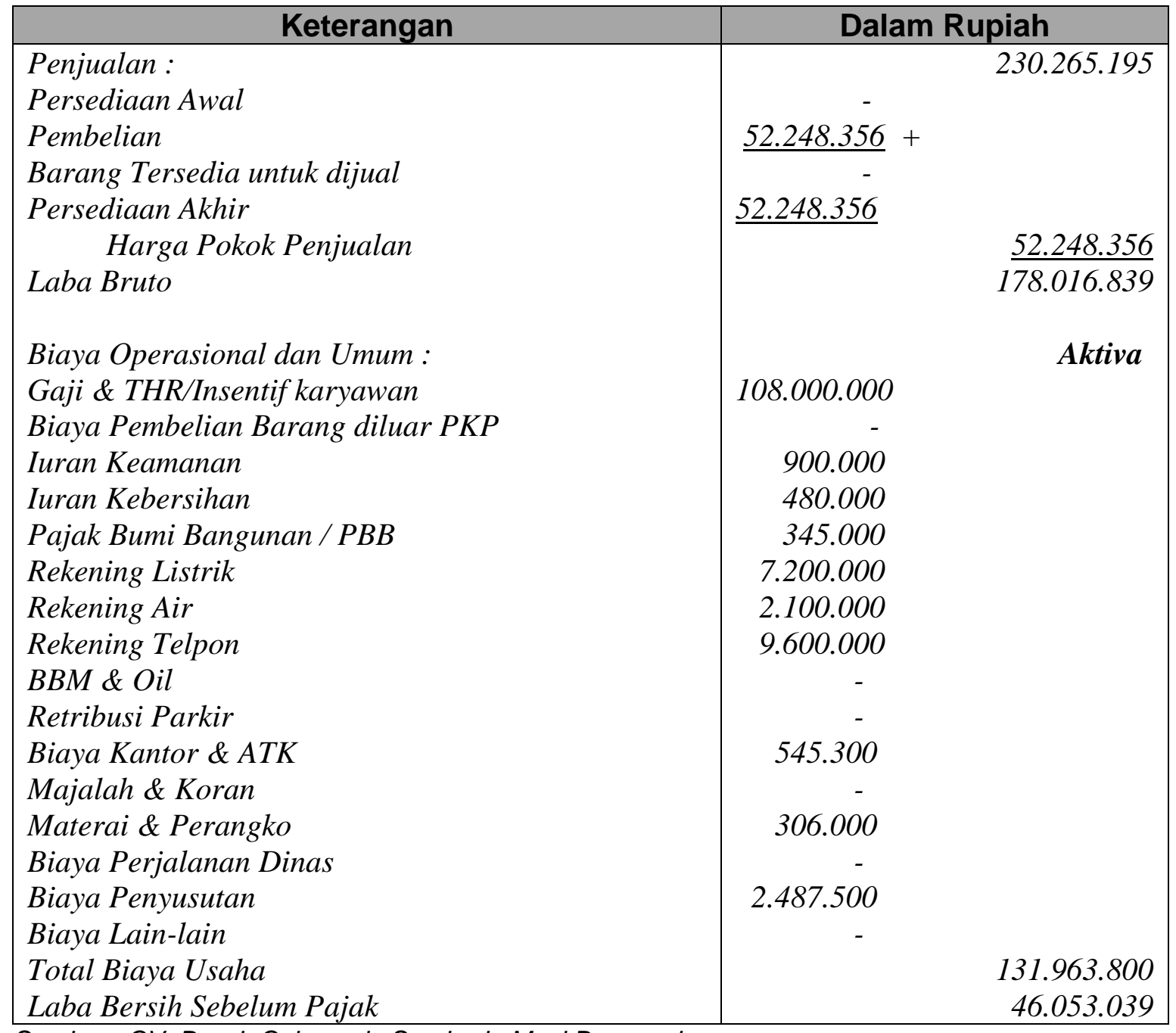

Sumber : CV. Bosch Cakrawala Sembada Musi Banyuasin

a) Hasil Analisis Pengedalian Biaya Operasional Pada CV. Bosch Cakrawala Sembada Musi Banyuasin

Untuk mengetahui peranan pengendalian biaya operasional yang dilakukan pihak manajemen dalam menjaga stabilitas biaya yang dikeluarkan, penulis memilih analisis varians untuk menilai tingkat pengendalian yang dilakukan perusahaan dalam upaya meningkatkan laba dan analisis rasio biaya operasional untuk melihat sejauh mana tingkat laba yang dihasilkan perusahaan.

\section{b) Metode Varians}

Teknik varians yaitu teknik yang digunakan untuk menilai pengendalian biaya operasional yang dilakukan perusahaan dengan melihat jumlah anggaran dan realisasi biaya operasional dimana jumlah realisasi biaya dikurangi jumlah anggaran biaya perusahaan sehingga dapat diketahui selisihnya.

Data yang digunakan meliputi laporan laba rugi, anggaran biaya operasional dan realisasi biaya operasional CV. Bosch Cakrawala Sembada Musi Banyuasin dari tahun 2016 sampai dengan 2018, berikut 
rincian yang dapat dijelaskan dari jumlah anggaran dan realisasi biaya perrusahaan sebagai berikut:

Tabel 4

Jumlah Anggaran dan Realisasi Biaya Operasional

CV. Bosch Cakrawala Sembada Musi Banyuasin

Periode 2016 (dalam rupiah)

\begin{tabular}{|c|l|r|r|}
\hline No. & \multicolumn{1}{|c|}{ Biaya } & $\begin{array}{c}\text { Jumlah anggaran } \\
\text { biaya operasional }\end{array}$ & $\begin{array}{c}\text { Jumlah realisasi } \\
\text { biaya operasional }\end{array}$ \\
\hline 1 & Harga pokok usaha & 130.100 .000 & 141.989 .312 \\
\hline 2 & Biaya listrik + telpon + air & 7.500 .000 & 8.755 .000 \\
\hline 3 & Kebutuhan Kantor & 15.200 .000 & 17.955 .000 \\
\hline \multicolumn{2}{r|}{ Total } & $\mathbf{1 5 2 . 8 0 0 . 0 0 0}$ & $\mathbf{1 6 8 . 6 9 9 . 3 1 2}$ \\
\hline
\end{tabular}

Sumber : CV. Bosch Cakrawala Sembada Musi Banyuasin (2016)

Pada Tahun 2016

a. Harga pokok usaha Jumlah anggaran biaya operasional untuk harga pokok usaha sebesar Rp.130.100.000, sedangkan jumlah realisasinya sebesar Rp.141.989.312 data tersebut menunjukkan terjadinya varians unfavorable terhadap harga pokok usaha (pembelian) yang mana selisihnya sebesar Rp. 11.889 .312 yang artinya belum terkendalinya biaya harga pokok usaha.

b. Biaya listrik + telpon + air

Pada biaya listrik, telpon dan air jumlah anggaran biaya operasionalnya sebesar Rp. 7.500.000, sedangkan jumlah biaya realisasinya sebesar Rp.8.755.000. dari hal tersebut dapat dilihat selisih sebesar Rp. 1.275.000 yang mana hal biaya tersebut belum terkendali. c. Kebutuhan kantor

Jumlah anggaran biaya operasional pada kebutuhan kantor sebesar Rp.15.200.000, dan jumlah realisasi biaya operasionalnya sebesar Rp.17.955.000. Dari data tersebut dapat dilihat bahwa pengendalian untuk kebutuhan kantor belum terkendali karena besar selisih antara keduanya sebesar Rp. 2.755.000.

d. Total biaya

Pada anggaran biaya operasional berjumlah sebesar Rp. 152.000.000, sedangkan jumlah realisasinya sebesar Rp. 168.699 .312 maka dari hasil penelitian didapat selisih sebesar Rp. 15.899.312.

Dari uraian diatas jumlah selisih yang dihasilkan bersifat negatif sehingga tidak menguntungkan bagi pihak perusahaan sesuai dengan efektifitas yang diharapkan walaupaun masih ada laba yang didapat dari pendapatan.

Tabel 5

Jumlah Anggaran dan Realisasi Biaya Operasional

CV. Bosch Cakrawala Sembada Musi Banyuasin

Periode 2017 (dalam rupiah)

\begin{tabular}{|c|l|r|r|}
\hline No. & \multicolumn{1}{|c|}{ Biaya } & $\begin{array}{c}\text { Jumlah anggaran } \\
\text { biaya operasional }\end{array}$ & $\begin{array}{c}\text { Jumlah realisasi } \\
\text { biaya operasional }\end{array}$ \\
\hline 1 & Harga pokok usaha & 110.050 .000 & 113.665 .208 \\
\hline 2 & Biaya listrik + telpon + air & 7.500 .000 & 7.545 .000 \\
\hline
\end{tabular}




\begin{tabular}{|r|c|r|r|}
\hline 3 & Biaya Kebutuhan Kantor & 15.200 .000 & 15.250 .000 \\
\hline Total & $\mathbf{1 3 2 . 7 5 0 . 0 0 0}$ & $\mathbf{1 3 6 . 4 6 0 . 2 0 8}$ \\
\hline
\end{tabular}

Sumber : CV. Bosch Cakrawala Sembada Musi Banyuasin (2017)

\section{Pada tahun 2017}

a. Harga pokok usaha Jumlah anggaran biaya operasional untuk biaya pokok usaha (pembelian) sebesar Rp.110.050.000 dan jumlah realisasinya sebesar Rp.113.665.208 dari data tersebut didapat selisih sebesar Rp.3.615.208.

b. Biaya listrik + telpon + air

Pada biaya listrik, telpon dan air jumlah anggaran biaya operasionalnya sebesar Rp.7.500.000 sedangkan jumlah realisasi biaya operasionalnya sebesar Rp.7.545.000 dari data tersebut dapat dilihat selisih sebesar Rp.45.000. c. Biaya kebutuhan kantor Jumlah anggaran biaya operasional untuk kebutuhan kantor sebesar Rp.15.200.000 sedangkan jumlah biaya realisasinya sebesar Rp.15.250.000, didapat selisih sebesar Rp.50.000.

d. Total biaya

Pada anggaran biaya operasional berjumlah sebesar Rp. 132.750.000 sedaangkan pada jumlah realisasi biaya operasionalnya berjumlah sebesar Rp.136.460.208 maka dari hasil penelitian didapat selisih sebesar Rp.3.710.208.

\section{Tabel 6 \\ Jumlah Anggaran dan Realisasi Biaya Operasional \\ CV. Bosch Cakrawala Sembada Musi Banyuasin}

Periode 2018 (dalam rupiah)

\begin{tabular}{|r|l|r|r|}
\hline No. & \multicolumn{1}{|c|}{ Biaya } & $\begin{array}{r}\text { Jumlah anggaran } \\
\text { biaya operasional }\end{array}$ & $\begin{array}{c}\text { Jumlah realisasi } \\
\text { biaya operasional }\end{array}$ \\
\hline 1 & Pembelian & 53.100 .500 & 52.246 .356 \\
\hline 2 & Gaji dan THR/Insentif & 110.500 .000 & 108.000 .000 \\
\hline 3 & luran keamanan & 700.000 & 900.000 \\
\hline 4 & luran kebersihan & 400.000 & 480.000 \\
\hline 5 & Pajak bumi dan bangunan & 320.000 & 345.000 \\
\hline 6 & Rekening listrik & 7.100 .000 & 7.200 .000 \\
\hline 7 & Rekening air & 2.250 .000 & 2.100 .000 \\
\hline 8 & Rekening telepon & 9.800 .000 & 9.600 .000 \\
\hline 9 & Biaya kantor ATK & 550.000 & 545.300 \\
\hline 10 & Materai dan perangko & 310.000 & 306.000 \\
\hline 11 & Biaya Penyusutan & 2.400 .000 & 2.487 .500 \\
\hline & Total & $\mathbf{1 8 7 . 4 3 0 . 5 0 0 0}$ & $\mathbf{1 8 4 . 2 1 0 . 1 5 6}$ \\
\hline
\end{tabular}

Sumber : CV. Bosch Cakrawala Sembada Musi Banyuasin (2018)

Pada tahun 2017

a. Pembelian

Jumlah anggaran biaya

operasional untuk pembelian berjumlah sebesar Rp. 53.100.500, sedangkan jumlah realisasinya sebesar Rp. 52.246.356 dari data tersebut dapat dilihat selisih sebesar Rp. 854.414 yang mana dari hasil tersebut bahwa biaya untuk pembelian pada tahun 2017 sudah terkendali atau favorable.

b. Gaji dan THR/ Insentif

Pada gaji dan THR jumlah anggaran biaya operasionalnya sebesar Rp.110.500.000 dan jumlah realisasinya sebesar Rp. 108.000.000 dapat dilihat selisih sebesar $R p$. 
110.500 .000 yang mana biaya tersebut sudah terkendali karena biaya anggaran lebih besar dari pada realisasinya.

c. Iuran keamanan

Jumlah anggaran biaya operasional untuk iuran keamanan sebesar Rp.700.000 sedangkan jumlah realisasinya sebesar $\mathrm{Rp}$. 900.000 dapat dilihat selisih sebesar Rp. 200.000 .

d. Iuran kebersihan

Jumlah anggaran biaya operasional untuk iuran kebersihan sebesar Rp.400.000 dan jumlah realisasinya sebesar Rp. 480.000 dapat dilihat selisinnya sebesar Rp. 80.000 .

e. Pajak bumi dan bangunan

Pada pajak bumi dan bangunan jumlah anggaran biaya operasionalnya sebesar Rp. 320.000 sedaangkan jumlah realisasinya sebesar $\mathrm{Rp}$. 345.000 yang mana dengan selisih sebesar Rp. 25.000.

f. Rekening listrik

Jumlah anggaran rekening listrik sebesar Rp. 7.100.000 dan jumlah realisasinya sebesar Rp. 7.200 .000 dapat dilihat selisih sebesar Rp.100.000.

g. Rekening air

Pada rekening listrik jumlah anggaran biaya operasionalnya sebesar Rp.2.250.000 dan jumlah realisasi biaya operasionalnya sebesar Rp.2.100.000 dengan selisih sebesar Rp. 150.000.

h. Rekening telepon

Jumlah anggaran untuk rekening telepon sebesar Rp. 9.800 .000 sedangkan jumlah realisasinya sebesar Rp. 9.600.000 dengan selisih sebesar Rp.200.000.

i. Biaya kantor ATK

Pada biaya kantor ATK jumlah anggaran biaya operasional sebesar Rp.550.000 sedangkan jumlah realisasinya sebesar Rp. $\quad 545.300$ dapat dilihat selisih sebesar Rp.4.700.

j. Materai dan perangko

Jumlah anggaran materai dan perangko sebesar Rp. $\quad 310.000$ sedangkan jumlah realisasinya sebesar Rp. 306.000 dengan selisih sebesar Rp. 4000.

k. Biaya penyusutan

Jumlah anggaran untuk biaya penyusutan (pemeliharaan) sebesar Rp.2.400.000 sedangkan jumlah realisasinya sebesar Rp. 2.487 .500 dengan selisih sebesar Rp. 87.500.

i. Total biaya

Total biaya pada jumlah anggaran sebesar Rp. 187.430 .500 sedangkan pada realisasi sebesar Rp.184.210.156 dengan selisih sebesar Rp.3.220.344.

\section{c) Tingkat Kenaikan Laba}

Setelah dilakukan analisis menggunakan teknik varians terhadap biaya operasional yang dikeluarkan oleh perusahaan yang mana mencari selisih antara jumlah anggaran biaya operasional dengan realisasi jumlah biaya operasional, kemudian dilakukan penilaian dengan teknik kenaikan laba.

Teknik kenaikan laba yaitu teknik yang membandingkan antara biaya operasional dengan pendapatan operasional perusahaan dikali dengan $100 \%$, sehingga terlihat persentase peningkatan atau penurunan laba yang dihasilkan perusahaan dari tahun 2016 sampai dengan 2018.

Teknik ini mengukur tingkat efektivitas pengelolahan perusahaan yang ditunjukkan oleh jumlah keuntungan yang dihasilkan dan menggambarkan kemampuan perusahaan untuk mendapatkan laba melalui semua kemampuan dan sumber uang ada pada perusahaan.

Data yang digunakan dalam penelitian ini adalah laporan laba rugi CV. Bosch Cakrawala Sembada Musi 
Banyuasin dari tahun 2016 sampai dengan 2018. Adapun rumus yang digunakan sebagi berikut :

$$
\text { BOPO }=\frac{\text { Biaya Operasional }}{\text { Pendapatan }} \times 100 \%
$$

$$
\text { Tahun } 2016=\frac{168.699 .312}{177.486 .640} \times 100 \%
$$$$
=95,05 \%
$$

$$
\text { Tahun } \begin{aligned}
2017 & =\frac{136.460 .208}{142.081 .510} \times 100 \% \\
& =96,04 \%
\end{aligned}
$$

$$
\text { Tahun } \begin{aligned}
2018 & =\frac{184.210 .156}{230.265 .195} \times 100 \% \\
& =79.99 \%
\end{aligned}
$$

Tingkat laba yang dimiliki CV. Bosch Cakrawala Sembada Musi Banyuasin mengalami kenaikan, terlihat pada perhitungan diatas berupa selisih anatar laba masa lalu dan sekarang.

Pada tahun 2016 laba yang dihasilkan sebesar 95,05\% dari laba yang dihasilkan, maka dapat disimpulkan laba yang didapatkan baik namun realisasi anggaran biaya operasional melebihi jumlah anggaran biaya operasional sehingga masih kurangnya pengendalian dalam biaya operasional.

Pada tahun 2017 laba yang dihasilkan sebesar 96,04\% sedangkan tahun yang sebelumnya sebesar 95,05\% dapat dilihat bahwa laba pada tahun ini mengalami kenaikan sebesar $0,99 \%$ atau $1 \%$ hal ini baik bagi perusahaan namun realisasi anggarannya masih memerlukan pengendalian sehingga laba yang didapatkan lebih optimal.

Pada tahun 2018 laba yang dihasilkan sebesar $79,99 \% \%$ hal ini terjadinya penurunan dari tahun sebelumnya yang mana sebesar 96,04 $\%$ dengan selisih sebesar 16,05 \%.
Hal ini mempengaruhi tingkat laba yang didapat perusahaan dimana pengeluaran yang keluarkan besar dari tahun sebelumnya sehingga mempengaruhi laba.

Dari uraian diatas rata-rata pertahun jumlah peningkatan laba yang dihasilkan positif namun melihat dari pada realisasi anggaran maka $\mathrm{CV}$. Bosch Cakrawala Sembada Musi Banyuasin harus lebih mampu memaksimalkan biaya yang harus dikeluarkan supaya laba yang dihasilkan terus meningkat.

\section{G. PEMBAHASAN}

Berdasarkan hasil analisis yang dilakukan bahwa tahun 2016 sampai dengan tahun 2018 terdapat beberapa yang tidak efisien antara jumlah anggaran biaya operasional dengan jumlah realisasi biaya operasional.

Pada tahun 2016 harga pokok usaha yang dianggarkan tidak sebanding dengan realisasi yang dilakukan dalam arti biaya operasional melebihi anggaran. Biaya listrik, telepon dan air pada tahun ini sebesar Rp.8.755.000 sedangkan anggarannya sebesar Rp. 7.500.000 dengan selisih sebesar Rp. 1.255.000 pada kebutuhan kantor jumlah anggaran sebesar Rp. 15.200 .000 namun realisasinya sebesar Rp. 17.955.000 dapat dilihat selisih sebesar Rp.2.755.000 yang harus ditanggung oleh perusahaan. Total biaya yang dianggarkan perusahaan sebesar Rp.152.800.000 tidak dapat tercapai karena biaya yang dipergunakan oleh perusahaan dalam melakukan aktivitasnya sebesar Rp.168.699.312 sehingga beban yang harus ditanggung perusahaan sebesar Rp.15.899.312.

Pada tahun 2017 harga pokok usaha sebesar Rp. 110.050.000 yang dianggarkan dengan realisasi sebesar Rp.113.665.208 hal ini tidak 
sebandingkan dengan anggaran yang mana selisih sebesar Rp.3.615.208. Biaya listrik, air dan telepon pada tahun ini juga kurang efisien karena anggaran sebesar Rp.7.500.000 dengan realisasi sebesar Rp.7.545.000 dan biaya kebutuhan kantor kurang efisien sebesar Rp.50.000. Total anggaran biaya operasional pada tahun ini sebesar Rp. 132.750.000 sedangkan jumlah realisasinya sebesar Rp.136.460.208 hal ini tidak efisien yang mana perusahaan harus menanggung beban sebesar Rp.3.710.208 untuk biaya operasional.

Pada tahun 2018 jumlah anggaran untuk pembelian sebesar Rp.53.100.500 sedangkan realisasinya sebesar Rp. 52.246.356 dengan selisih sebesar Rp.854.144 untuk tahun ini efisiensi dalam anggaran sudah terkendali seperti biaya gaji dan THR, rekening air, rekening telepon, biaya kantor ATK, materai dan perangko. Pada biaya yang lain belum terlalu efisien seperti iuran keamanan dengan jumlah anggaran sebesar Rp.700.000 namun realisasinya sebesar Rp.900.000 dengan selisih Rp.200.000 begitu pula dengan iuran kebersihan dengan reaalisasi sebesar Rp.480.000 dan anggaran sebesar Rp.400.000. Total anggaran biaya operasional pada tahun ini sebesar Rp.187.430.500 sedangkan realisasi sebesar Rp.184.210.156 dengan selisih sebesar Rp.3.220.344 hal ini dapat dilihat bahwa pengendalian biaya operasional pada tahun ini sudah efisien oleh karena itu laba yang dihasilkan pada tahun ini lebih besar.

Pada tahun 2016 dan 2017 terdapat penurunan pendapatan dimana pada tahun 2016 sebesar Rp.177.486.640 dan pada tahun 2017 sebesar Rp.142.081.510, hal ini dapat terjadi karena beberapa hal, diantaranya berkurangnya penjualan, turunya permintaan konsumen dan adanya pesaing baru. Hal ini membuat menurunnya permintaan atas penjualan mesin, pendapatan poto kopi maupun penjualan dari ATK.

Pada tahun 2018 terjadi peningkatan pendapatan dimana pendapatan pada tahun ini sebesar Rp.230.265.195, dalam hal ini sebanding dengan biaya yang dikeluarkan dimana biaya operasional pada tahun ini lebih besar dari pada tahun sebelumnya. Peningkatan hasil penjualan berdasarkan spekulasi dapat terjadi karena masih adanya stok barang pada tahun kemarin yang belum terjual sehingga pada tahun ini dapat terjual habis.

Jadi anggaran yang dilakukan oleh CV. Bosch Cakrawala Sembada Musi Banyuasin dari tahun 2016 sampai dengan 2018 terdapat beberapa anggaran biaya operasional yang tidak efisien, namun dibandingkan dengan tahun sebelumnya tahun 2017 jauh lebih baik, hal ini dapat dilihat dari realisasi anggaran tidak melebihi daripada jumlah anggaran yang dibuat.

\section{G. KESIMPULAN DAN SARAN \\ 1. Kesimpulan}

Dari analisa yang dilakukan penulis, maka penulis menyimpulkan:

a) Hasil analisa yang dilakukan peneliti memperlihatkan bahwa pada tahun 2016 dan 2017 terjadinya varians yang unfavorable, dimana pada tahun tersebut jumlah realisasi anggaran selalu lebih besar dari jumlah yang dianggarkan, hal tersebut dapat mengurangi jumlah laba yang dihasilkan perusahaan. Sedangkan pada tahun 2018 terjadinya varian favorable karena jumlah realisasi anggaran tidak melebihi jumlah anggaran yang dibuat sehingga laba yang dihasilkan meningkat. 
b) Dapat dilihat pada tahun 2016 persentase laba yang dihasilkan perusahaan sebesar 95,05\% , kemudian pada tahun 2017 mengalami kenaikan sebesar $0,99 \%$ atau $1 \%$ menjadi $96,05 \%$ seterusnya pada tahun 2018 laba yang didapatkan mengalami penurunan sebesar $16,05 \%$ menjadi $79,99 \%$ dimana biaya operasional lebih besar dari pada tahun sehingga tingkat laba menurun.

Dengan demikian pengendalian biaya operasional yang dilakukan CV. Bosch Cakrawala Sembada Musi Banyuasin sudah baik namun harus mampu memaksimalkan pengendalian biaya operasional kembali sehingga laba yang akan dihasilkan meningkat.

\section{Saran}

Adapun saran untuk CV. Bosch Cakrawala Sembada Musi Banyuasin dalam menjaga biaya operasional sebagai berikut :

a) CV. Bosch Cakrawala Sembada Musi Banyuasin diharapkan dapat lebih meningkatkan pengendalian terhadap biaya operasional lebih efisien lagi agar jangan sampai keperluan realisasi/lapangan lebih besar dari anggaran, sehingga laba yang dihasilkan dapat meningkat dan sesuai dengan tujuan yang diharapkan.

b) CV. Bosch Cakrawala Sembada Musi Banyuasin harus mampu berhatihati dalam menyusun anggaran biaya operasional agar laba yang didapat terus meningkat, seperti pengeluaran yang dibuat harus lebih tepat lagi supaya realisasi tidak lebih besar daripada anggaran. Dan harus mampu mengendalikan laba yang didapatkan karena dengan melihat peluang pengeluaran biaya tiba-tiba misalnya kerusakan mesin yang mana tidak dapat diprediksi kapan terjadi sehingga saat hal ini terjadi anggaran untuk kerusakan mesin, ataupun penyusutan yang lain sudah dapat diatasi dengan baik dan membuat suatu prosedur kerja untuk meminimalisirkan kecelakan kerja bagi kesejahteraan karyawan.

\section{DAFTAR PUSTAKA}

Carter, William K. 2009. Akuntani Biaya. Jakarta : Salemba Empat

Lestari, Wiwik dan Permana Bagus, Dhyka. 2017. Akuntansi Biaya Dalam Persepektif Manajerial. Depok: Rajawali Pers.

Mulyadi. 2007. Akuntansi Biaya. Yogyakarta: Sekolah Tinggi Ilmu Manajemen YKPN.

Mulyadi. 2010. Akuntansi Biaya. Yogyakarta: Sekolah Tinggi Ilmu Manajemen YKPN.

Riza Salman, Kautsar. 2016. Akuntansi Biaya Pendekatan Product Costing, Edisi Kedua. Jakarta Barat: Indeks.

Rudianto. 2013. Akuntansi Manajemen Informasi Untuk Pengambilan Keputusan. Jakarta: Penerbit Erlangga.

Siregar, Baldric dkk. 2016. Akuntansi Biaya. Jakarta: Salemba Empat.

Sugiyono. 2017. Metode Penelitian Kuantitatif, Kualitatif, Dan R\&D. Bandung: Alfabeta.

Syahrul dan Nizar. 2000. Kamus Lengkap Akuntansi. Jakarta: Citra Harta Pratama.

Wikipedia. 2017. Pengertian Laba.https://id. wikipedia.org/wiki/ Laba (Diakses pada tanggal 27 April 2018). 